\title{
KINERJA PEGAWAI DALAM PELAYANAN PUBLIK PADA DINAS PENDAPATAN DAERAH KABUPATEN BARITO TIMUR
}

\author{
Ginarta, Irawanto, Akmad Abdurahman \\ Sekolah Tinggi Ilmu Administrasi Bina Binua Banjarmasin \\ Email: irawanto67@gmail.com
}

\begin{abstract}
The aims of this research are: 1) To know the performance of employees in public service at Regional Revenue Service of East Barito Regency, 2) To know the obstacles in public service at Regional Revenue Service of East Barito Regency, and 3) to know solution to overcome obstacle in public service in the District Revenue Office of East Barito Regency.This research is a qualitative research. The key informant in this research is Head of Regional Revenue Service of East Barito Regency. Data were collected through interviews, observation and documentation.The results showed that: 1) Performance of employees of Revenue Service Office of East Barito Regency seen from performance indicators such as quality, effectiveness and work commitment is good but the quantity of work, the timeliness of task implementation, independence in dealing with work problems on PBB-P2 and BPHTB still not implemented optimally. 2) Obstacles faced in Public Service in the District Revenue Office of East Barito Regency, namely: a) Employee Performance not yet optimal, b) Lack of Employee Competency and Socialization, and c) Lack of Room Facilities Waiting, and 3) Solutions Can Do To Overcoming Obstacles in Public Service in the District Revenue Office of East Barito Regency, namely: a) Employee Development and Evaluation b) Technical Guidance (Bimtek) and Socialization, and c) The addition of waiting room facilities.
\end{abstract}

Keywords: performance, employee, public service.

\section{PENDAHULUAN}

Pelayanan publik menjadi suatu tolak ukur kinerja Pemerintah yang paling kasat mata. Masyarakat dapat langsung menilai kinerja pemerintah berdasarkan kualitas layanan publik yang diterima, karena kualitas layanan publik dirasakan masyarakat dari semua kalangan, dimana keberhasilan dalam membangun kinerja pelayanan publik secara profesional, efektif, efisien, dan akuntabel akan meng-angkat citra positif Pemerintah Kabupaten Barito Timur terkhusus Dinas Pendapatan Daerah Kabupaten Barito Timur di mata warga masyarakatnya.

Pelayanan yang diberikan oleh aparatur Pemerintah yang diselengga-rakan di Dinas Pendapatan Daerah Kabupaten Barito Timur disamping bersifat administrasi dan teknis, juga mempunyai aspek yuridis berupa kepastian hukum dan jaminan hukum. Sesuai dengan Peraturan Daerah Ka-bupaten Barito Timur Nomor 4 Tahun 2014 disebutkan bahwa Dinas
Pendapatan Daerah merupakan unsur pelaksana otonomi daerah di bidang pendapatan daerah yang bertugas melaksanakan urusan pemerintahan daerah berdasarkan asas otonomi dan tugas pembantuan di bidang Pendapatan Daerah.

Pelayanan yang dilaksanakan pada Dinas Pendapatan Daerah meliputi pelayanan pembuatan Nomor Pokok Wajib Pajak Daerah (NPWPD), pembuatan ijin rek-lame, ijin pertokoan, pajak parkir, Surat Ketetapan Retribusi Daerah (SKRD). Salah satunya yakni menye-lenggarakan pelayanan umum pelayanan PBB-P2 (Pajak Bumi dan Ba-ngunan Perdesaan dan Perkotaan) dan BPHTB (Bea Perolehan Hak atas Ta-nah dan Bangunan), yang meliputi pelayanan pendaftaran objek baru, mutasi objek pajak, pencetakan salinan Surat Pemberitahuan Pajak Terutang (SPPT), pembetulan SPPT, pemba-talan SPPT, 
keberatan, pengurangan, restitusi/ kompensasi, penentuan kembali tanggal jatuh tempo, Surat keterangan Nilai Jual Objek Pajak (NJOP),serta konsultasi.

Pajak pada sektor ini sangat penting untuk menunjang dan menopang pembiayaan penyelenggaraan peme-rintahan dan pembangunan secara ma-ndiri dan berkelanjutan pada Kabu-paten Barito Timur karena PBB-P2 dan BPHTB merupakan salah satu sumber Pendapatan Asli Daerah.

PBB-P2 (Pajak Bumi dan Bangu-nan Perdesaan dan Perkotaan) adalah pajak atas bumi dan bangunan yang dimiliki, dikuasai, dan/atau dimanfa-atkan oleh orang pribadi atau badan. Objek Pajak Bumi dan Bangunan perdesaan dan perkotaan adalah bumi dan /atau bangunan yang dimiliki, dikuasai, dan/atau dimanfaatkan oleh orang pribadi atau badan, kecuali ka-wasan yang digunakan untuk kegiatan usaha perkebunan, perhutanan dan pertambangan. BPHTB adalah pajak yang dikenakan atas perolehan hak atas tanah dan bangunan.Perolehan atas hak atas tanah dan/atau bangunan adalah perbuatan atau peristiwa hukum yang mengakibatkan diperoleh-nya atau dimilikinya hak atas tanah dan/atau bangunan oleh orang perseorangan pribadi atau badan. Objek BPHTB adalah perolehan hak atas tanah dan/atau bangunan. Subjek BPHTB adalah orang pribadi atau badan yang memperoleh hak atas tanah dan/atau bangunan.

Setiap pegawai pasti memiliki kinerja, kemampuan serta pengetahuan yang berbedabeda,begitu pula dalam pelayanan PBB-P2 dan BPHTB,dima-na dalam pelaksanaannya kualitas, kuantitas, ketepatan waktu, efektivitas, kemandirian dan komitmen kerja tidak memenuhi harapan/tujuan yang di-harapkan organisasi, dalam hal ini Dinas Pendapatan Daerah Kabupaten Barito Timur. Hal ini dapat dilihat pada kenyataan di lapangan, permasalahan juga tidak hanya datang dari masya-rakat sebagai pemohon tetapi juga dari pegawai pelaksana pelayanan yang kurang cermat dan tidak menguasai jenis pelayanan yang menjadi bidang tugasnya. Halini dapat dilihat dari waktu yang dibutuhkan untuk memproses pelayanan yang diperlukan oleh masyarakat. Hal ini dikarenakan adanya
Pegawai yang tidak teliti saat menerima berkas atau formulir permo-honan dari masyarakat, dimana seri-ngkali formulir diterima begitu saja bukan hanya dari Pegawai bagian pendaftaran tetapi juga pada pegawai bagian disposisi dimana Pegawai bersangkutan cenderung memberikan dis-posisi terhadap seluruh permohonan tanpa melakukan koreksi terlebih dahulu terhadap data yang masuk. Apabila data yang dimasukkanoleh pemohon tidak lengkap atau tidak sesuai dengan kenyataan yang ada, maka Dinas Pendapatan Daerah Kabupaten Barito Timur tidak dapat menye-lenggarakan pelayanan yang diminta oleh masyarakat yang diminta kecuali si pemohon telah melengkapi dan memperbaiki data tersebut dengan menyertakan dokumen pendukung. Perilaku kurang teliti ini pada akhirnya akan menyebabkan dokumen dan pelayanan yang seharusnya bisa diselesaikan dalam waktu 3 (tiga) hari harus ditunda beberapa hari bahkan sampai satu atau dua minggu sampai si pemohon melengkapi data dan berkas yang diperlukan, hal inilah yang me-nyebabkan begitu rendahnya volume warga masyarakat kabupaten Barito Timur pada umumnya untuk mendaftarkan diri mengurus PBB-P2 dan BPHTB.

Berdasarkan pada uraian diatas, maka perlu kiranya dilakukan pendalaman lebih lanjut lagi mengenai kinerja pegawai dalam pelayanan publik pada Dinas Pendapatan Daerah Kabupaten Barito Timur serta agar dapat mengetahui kendala atau ham-batan dalampelayanan publik serta solusi untuk mengatasi kendala tersebut.

\section{TINJAUAN PUSTAKA}

\section{Kinerja}

Menurut Wibowo (2010:7) kinerja berasal dari pengertian performance yang merupakan hasil pekerjaan yang mempunyai hubungan kuat dengan tujuan strategis organisasi, kepuasan konsumen, dan memberikan kontribusi pada ekonomi.

Menurut pendapat Agus Dharma (2014:30) kinerja adalah sesuatu yang dikerjakan atau produk/jasa yang dihasilkan atau diberikan seseorang atau sekelompok orang. Pengertian kinerja dalam hal ini dilihat dari dua 
sisi, yaitu dari sisi individu dan dari sisi organisasi.

Menurut Wibowo (2010:101) indikator kinerja atau performance indicators kadangkadang diperguna-kan secara bergantian dengan ukuran kinerja (performance measures). Pengukuran kinerja berkaitan dengan hasil yang dapat dikuantitatifkan dan mengusahakan data setelah kejadian.

Menurut Robbins (2013:121) ha-kekat penilaian kinerja individu adalah hasil kerja yang optimal. Penilaian kinerja dapat dilihat dari indikator:

1) Kualitas kerja

2) Kuantitas

3) Ketepatan waktu

4) Efektivitas

5) Kemandirian.

6) Komitmen Kerja.

Penilaian kinerja banyak digunakan di Great Britain dalam Abdullah (2014:50) adalah untuk :

1. Meningkatkan kinerja

2. Menetapkan tujuan organisasi

3. Mengidentifikasi pelatihan dan kebutuhan pengembangan.

Setiap aktivitas pekerjaan yang merupakan bagian organisasi perlu di-lakukan evaluasi yang dilakukan terus menerus.Penilaian yang dilakukan secara sistematis untuk mengetahui hasil pekerjaan karyawan dan kinerja organisasi.Disamping itu, juga untuk menentukan kebutuhan pelatihan kerja secara tepat, memberikan tanggung jawab yang sesuai kepada karyawan sehingga dapat melaksanakan peker-jaan yang lebih baik di masa men-datang dan sebagai dasar untuk menentukan kebijakan.

\section{Pelayanan Publik}

Definisi pelayanan menurut Rahayu (2011:8) adalah suatu proses pemberian sesuatu (baik jasa maupun produk) kepada orang lain. Berdasar-kan pengertian tersebut lebih ditekankan pada "Bagaimana pelayanan pub-lik (Aparatur Negara) dalam memper-lakukan masyarakat sebagai klien negara, untuk mengurus kepentingan-nya yang berhubungan dengan kepen-tingan dan tata tertib negara maka yang lebih diutamakan oleh masya-rakat dalam memdapatkan pelayanan harus memenuhi beberapa kriteria seperti adanya transparasi (keter-bukaan) pelayanan, adanya Akuntabi-litas (pertanggungjawaban) pelayanan dan kesamaan dalam pelayanan.

Soetopo (2014 : 7) pelayanan pri-ma, adalah pelayanan yang sangat baik atau pelayanan yang terbaik.

2.1.1 Pelayanan Publik Menurut UndangUndang Nomor 25 tahun 2009

Menurut Undang-Undang Nomor 25 tahun 2009 Pelayanan publik ada-lah kegiatan atau rangkaian kegiatan dalam rangka pemenuhan kebutu-han pelayanan sesuai dengan peratu-ran perundang-undangan bagi setiap warga negara dan penduduk atas barang, jasa, dan/atau pelaya-nan administratif yang disediakan oleh penyelenggara pelayanan publik.

Ruang lingkup pelayanan publik menurut Undang-Undang Pelayanan Publik meliputi pelayanan barang publik dan jasa publik serta pelayanan administratif yang diatur dalam peraturan perundang-undangan. Dalam ruang lingkup tersebut, termasuk pen-didikan, pengajaran, pekerjaan dan usaha, tempat tinggal, komunikasi dan informasi, lingkungan hidup, keseha-tan, jaminan sosial, energi, perbankan, perhubungan, sumber daya alam, pari-wisata, dan sektor strategis lainnya. (Pasal 5 UU No 25 Tahun 2009)

Organisasi penyelenggaraan pela-yanan publik sebagaimana maksud diatas, sekurangkurangnya meliputi:

a. pelaksanaan pelayanan;

b. pengelolaan pengaduan masya-rakat;

c. pengelolaan informasi;

d. pengawasan internal;

e. penyuluhan kepada masyarakat; dan

f. pelayanan konsultasi. (Pasal 8 UU No 25 Tahun 2009)

Untuk kebutuhan biaya/tarif pela-yanan publik, pada dasarnya meru-pakan tanggung jawab negara dan/atau masyarakat. Apabila dibebankan kepada masyarakat atau penerima pelayanan, maka penentuan biaya/tarif pelayanan publik tersebut ditetapkan dengan persetujuan Dewan Perwa-kilan Rakyat, Dewan Perwakilan Rak-yat Daerah Provinsi, Dewan Perwa-kilan Rakyat Daerah Kabupaten/Kota dan berdasarkan peraturan per-undangundangan. (Pasal 31 UU No 25 Tahun 2009) 
Pengawasan penyelenggaraan pe-layanan publik dilakukan oleh penga-was internal dan pengawas eksternal. Pengawasan internal penyelenggaraan pelayanan publik dilakukan melalui pengawasan oleh atasan langsung sesuai dengan peraturan perundang-undangan; dan pengawasan oleh pengawas fungsional sesuai dengan peraturan perundangundangan.Sem-entara pengawasan eksternal penye-lenggaraan pelayanan publik dilaku-kan melalui:

a. pengawasan oleh masyarakat be-rupa laporan atau pengaduan masyarakat dalam penyeleng-garaan pelayanan publik;

b. pengawasan oleh ombudsman se-suai dengan peraturan perundang-undangan; dan

c. pengawasan oleh Dewan Perwa-kilan Rakyat, Dewan Perwakilan Rakyat Daerah Provinsi, Dewan Perwakilan Rakyat Daerah Kabu-paten/Kota. (Pasal 35 UU No 25 Tahun 2009)

Penyelenggara berkewajiban me-nyediakan sarana pengaduan dan menugaskan pelaksana yang kompeten dalam pengelolaan pengaduan serta berkewajiban mengumumkan namadan alamat penanggung jawab penge-lola pengaduan serta sarana pengaduan yang disediakan. Penyelenggara ber-kewajiban mengelola pengaduan yang berasal dari penerima pelayanan, reko-mendasi ombudsman, Dewan Perwa-kilan Rakyat, Dewan Perwakilan Rak-yat Daerah Provinsi, dan Dewan Perwakilan Rakyat DaerahKabupaten/Kota dalam batas waktu tertentu. Penyelenggara berkewajiban menindaklanjuti hasil pengelolaan pengaduan tsb. (Pasal 36 UU No 25 Tahun 2009)

\section{METODE PENELITIAN}

Dalam Penelitian ini pendekatannya lebih kepada metode kualitatif karena Penulis ingin mendalami bagaimana sebenarnya Kinerja Pegawai pada Dinas Pendapatan Daerah Kabupaten Barito Timur dalam Pelayanan PBBP2 dan BPHTB.

Untuk mengetahui terkait dengan kinerja terhadap Pelayanan PBB-P2 dan BPHTB pada Dinas Pendapatan Daerah, maka jadi sumber data didalam penelitian ini adalah atasan langsung baik dari Kepala Sub Bidang dan
Kepala Bidang untuk mengetahui bagaimana persepsi masyarakat terkait Pelayanan Publik, serta masyarakat saat berlangsungnya pelayanan, pene-liti menentukan sumber informasi dengan teknik aksidental.

Adapun yang menjadi key in-forman dalam penelitian ini adalah Kepala Dinas Pendapatan Daerah Kabupaten Barito Timur.

Pengumpulan data dalam peneli-tian ini dilakukan melalui wawancara, Observasi, dan Dokumentasi

Dalam penelitian ini, analisa data yang dilakukan adalah dengan cara : (1) Teknik analisa kualitatif, yaitu penganalisaan melalui tabel deskripsi dari hasil wawancara, catatan hasil observasi lapangan seperti kondisi pada saat pelayanan. (2) Reduksi data, dengan membuat abstraksi dari data yang diperoleh dari hasil wawancara. (3) Penyusunan ke dalam satuan-satuan, tabel dan matrik dengan mengklasifikasikan data dari hasil wawancara.

\section{HASIL DAN PEMBAHASAN}

\section{KinerjaPegawai Dalam Pela-yanan Publik Di Dinas Penda-patan Daerah Kabupaten Barito Timur.}

Salah satu tugas dari Dinas Pen-dapatan Daerah Kabupaten Barito Timur adalah menyelenggarakan pela-yanan PBB-P2 dan BPHTB.

Hasil observasi bahwa petugas pelayanan merupakan unsur yang pa-ling utama dalam memberikan pela-yanan, karena petugas ini yang lang-sung berhubungan dengan pengguna jasa, perbaikan yang dilakukan adalah dengan memberikan arahan kepada petugas agar lebih sopan dan ramah dalam menghadapi pengguna jasa.

Kinerja pegawai Dinas Pendapa-tan Daerah Kabupaten Barito Timur dalam melaksanakan pelayanan PBB-P2 dan BPHTB dapat dilihat melalui 6 (enam) aspek, yaitu kualitas, kuantitas, ketepatan waktu, efektivitas, keman-dirian, dan komitmen kerja.

Kinerja pegawai apabila dilihat dari kualitas kerja adalah bagus, kare-na pegawai melaksanakan pelayanan PBB-P2 dan BPHTB sesuai dengan prosedur yang telah ditentukan. 
Hasil wawancara tersebut senada dengan pendapat Robbins (2013:121) yang menyatakan kualitas kerja yang baik merupakan hasil aktivitas yang dilakukan mendekati sempurna dalam arti menyesuaikan beberapa cara yang ideal dari penampilan aktivitas atau-pun memenuhi tujuan-tujuan yang diharapkan di suatu aktivitas kualitas kerja yang diukur melalui persepsi pegawai terhadap kualitas pekerjaan yang dihasilkan serta kesempurnaan tugas terhadap keterampilan dan kemampuan pegawai.

Selain melalui aspek kualitas, kinerja pegawai Dinas Pendapatan Daerah Kabupaten Barito Timur dalam melaksanakan pelayanan PBB-P2 dan BPHTB juga dilihat berda-sarkan pada aspek kuantitas. Kuantitas kerja merupakan ukuran seberapa banyak pekerjaan dapat dilaksanakan dalam satu periode. Sehubungan dengan hal tersebut maka kuantitas kerja yang dimaksud dalam penelitian ini adalah seberapa banyak pegawai pada Dinas Pendapatan Daerah Kabu-paten Barito Timur dapat melaksana-kan pelayanan PBB-P2 dan BPHTB dalam satu hari. Apabila dilihat dari aspek kuantitas kerja adalah masih belum optimal karena pegawai masih ada yang belum mampu menyelesai-kan seluruh permohonan pelayanan PBB-P2 dan BPHTB yang masuk dalam 1 (satu) hari kerja.

Sesuai dengan pendapat Robbins (2013: 121) bahwa kuantitas merupa-kan jumlah yang dihasilkan, dinyata-kan dalam istilah seperti jumlah unit, jumlah siklus aktifitas yang diselesai-kan karyawan, dan jumlah aktivitas yang dihasilkan.

Selanjutnya kinerja pegawai Dinas Pendapatan Daerah Kabupaten Barito Timur dalam melaksanakan pelayanan PBB-P2 dan BPHTB juga dilihat dari aspek ketepatan waktu. Ketepatan waktu disini mencakup kemampuan pegawai dalam menye-lenggarakan pelayanan PBB-P2 dan BPHB sesuai dengan standar waktu yang ditentukan yaitu 1 (satu) hari. Kinerja pegawai Dinas Pendapatan Kabupaten Barito Timur dalam pelak-sanaan pelayanan PBB-P2 dan BPHTB khususnya apabila dilihat dari ketepatan waktu adalah masih kurang optimal dikarenakan adanya pegawai yang masih belum mampu menye-lesaikan pelayanan PBB-P2 dan BPHTB sesuai dengan standar waktu yang ditentukan. Keterlambatan pe-nyelesaian pelayanan PBB-P2 dan BPHTB itu bukan hanya berasal dari pegawai Dinas Pendapatan Daerah Kabupaten Barito Timur, tetapi juga dikarenakan berkas dari masyarakat yang kurang lengkap.

Robbins (2013:121) menyatakan ketepatan waktu adalah tingkat suatu aktivitas diselesaikan pada awal waktu yang diinginkan dilihat dari sudut ko-ordinasi dengan hasil output serta memaksimalkan waktu yang tersedia untuk aktivitas lain. Ketepatan waktu diukur dari persepsi pegawai terhadap suatu aktivitas yang diselesaikan diawal waktu sampai menjadi output.

Kinerja pegawai dalam melaksa-nakan pelayanan PBB-P2 dan BPHTB juga dilihat dari efektivitas kerja pega-wai. Efektivitas kerja merupakan suatu ukuran tentang pencapaian suatu tugas atau tujuan yang dalam penelitian ini adalah berkaitan dengan pelayanan PBB-P2 dan BPHTB pada Dinas Pendapatan Kabupaten Barito Timur. Pegawai pada Dinas Pendapatan Daerah Kabupaten Barito Timur beru-saha melaksanakan pelayanan PBB-P2 dan BPHTB dengan seefektif mung-kin. Hal ini ditunjukkan dengan pega-wai yang berupaya memaksimalkan jam kerja yang ada untuk menyele-nggarakan pelayanan PBB-P2 dan BPHTB kepada masyarakat yang memerlukan.

Efektifitas kerja yang dicapai pegawai Dinas Pendapatan Kabupaten Barito Timur sesuai dengan pendapat Robbins (2013:121) yang menyatakan efektifitas sebagai tingkat penggunaan sumber daya organisasi (tenaga, uang, teknologi, bahan baku) dimaksimalkan dengan maksud menaikkan keuntu-ngan dari setiap unit dalam penggu-naan sumber daya, persepsi pegawai dalam menjalankan tugas, efektivitas penyelesaian tugas yang ditentukan organisasi.

Kinerja pegawai dalam melaksa-nakan pelayanan PBB-P2 dan BPHTB di Dinas Pendapatan Kabupaten Barito Timur juga dilihat berdasarkan aspek kemandirian. Kemandirian disini lebih mengarah kepada kemampuan pegawai dalam melaksanakan pelayanan PBB-P2 dan BPHTB secara mandiri dan mengatasi permasalahan yang mungkin ditemui selama penyelengga-raan pelayanan PBB-P2 dan 
BPHTB tersebut secara mandiri. Kinerja pegawai pada Dinas Pendapatan Daerah Kabupaten Barito Timur dalam melak-sanakan pelayanan PBB-P2 dn BPHTB khususnya apabila dilihat dari aspek kemandirian adalah masih ku-rang, karena rata-rata pegawai masih kurang memiliki kemampuan untuk mengatasi permasalahan kerja masing-masing secara sendiri dan cenderung menunggu pegawai lainnya dan atasan yang lebih tahu cara untuk menangani permasalahan yang ada pada bidang PBB-P2 dan BPHTB.

Robbins (2013:121) menyatakan bahwa kemandirian merupakan tingkat dimana seorang pegawai dapat mela-kukan fungsi kerjanya tanpa meminta bantuan, bimbingan dari pengawas, atau keterlibatan pengawas mencam-puri kerja pegawai untuk menghindari hasil yang merugikan. Kemandiriaan akan diukur dari persepsi pegawai ter-hadap tugas dalam melakukan fungsi kerjanya masing-masing pegawai se-suai dengan tanggung jawab pegawai itu sendiri.

Kinerja pegawai dalam melaksa-nakan pelayanan PBB-P2 dan BPHTB pada Dinas Pendapatan Daerah Kabu-paten Barito Timur juga dilihat ber-dasarkan pada Komitmen Kerja. Ko-mitmen kerja merupakan kondisi di mana pegawai sangat tertarik terhadap tujuan, nilainilai, dan sasaran orga-nisasinya. Komitmen kerja seorang pe-gawai lebih dari sekedar keanggotaan formal, karena meliputi sikap menyu-kai organisasi dan kesediaan untuk mengusahakan tingkat upaya yang tinggi bagi kepentingan organisasi demi pencapaian tujuan.Jadi komi-tmen kerja pegawai mencakup unsur loyalitas terhadap organisasi, keterli-batan dalam pekerjaan, dan identi-fikasi terhadap nilai-nilai dan tujuan organisasi.Di samping itu komitmen kerja pegawai mengandung pengertian sebagai suatu hal yang lebih dari sekedar kesetiaan yang pasif melain-kan menyiratkan hubungan pegawai dengan organisasi secara aktif.Karena pegawai yang menunjukkan komitmen tinggi memiliki keinginan untuk mem-berikan tenaga dan tanggungjawab ya-ng lebih dalam menyokong kesejahte-raan dan keberhasilan organisasinya.

Robbins (2013:121) menyatakan bahwa komitmen kerja merupakan tingkat dimana pegawai mempunyai komitmen kerja dengan organisasi dan tanggung jawab pegawai terhadap organisasi.Pengukuran dengan meng-gunakan persepsi pegawai dalam membina hubungan dengan organisasi dan tanggung jawab, loyalitas terhadap organisasi.

Dapat disimpulkan bahwa kinerja pegawai Dinas Pendapatan Daerah Kabupaten Barito Timur dalam mela-ksanakan pelayanan PBB-P2 dan BPHTB adalah bagus. Hal ini ditun-jukkan dengan adanya hasil kerja dengan indikator seperti kualitas, efek-tivitas dalam memaksimalkan jam kerja, serta komitmen kerja yang tinggi dalam setiap pelaksanaan tugas dan tanggung jawab, walaupun ada sebagian masyarakat dalam hal kuantitas ,ketepatan waktu dalam pelayanan dan kemandirian kerja dalam menghadapi masalah pada pelayanan masih diselenggarakan tidak sesuai.

Dinas Pendapatan Daerah Kabu-paten Barito Timur masih belum memiliki sarana penunjang pelayanan PBB-P2 dan BPHTB yang cukup memadai. Dinas Pendapatan Daerah Kabupaten Barito Timur memiliki pegawai yang mampu menyelengga-rakan pelayanan PBB-P2 dan BPHTB sesuai dengan prosedur dan peraturan yang berlaku. Hal ini sesuai dengan amanat yang tertuang dalam Pasal 13 UU No 25 Tahun 2009Selain kerjasama, penyelenggara juga dapat melakukan kerja sama tertentu dengan pihak lain untuk menyelenggarakan pelayanan publik. Kerja sama tertentu merupakan kerja sama yang tidak melalui prosedur seperti yang dijelas-kan diatas, dan penyelenggaraannya tidak bersifat darurat serta harus dise-lesaikan dalam waktu tertentu. Petugas penyelenggara pelayanan PBB-P2 dan BPHTB pada Dinas Pendapatan Daerah Kabupaten Barito Timur memiliki respon dan sikap tanggap yang cepat terhadap kebutuhan masyarakat.Petugas penyelenggara pelayanan PBB-P2 dan BPHTB pada Dinas Pendapatan Daerah Kabupaten Barito Timur bersikap sopan dan santun dalam menghadapi masyarakat yang mengurus pelayanan PBB-P2 dan BPHTB. Petugas penyelenggara pelayanan $\mathrm{PBB}-\mathrm{P} 2$ dan BPHTB pada Dinas Pendapatan Daerah Kabupaten Barito Timur memiliki empati yang tinggi yang ditunjukan dengan sikap tegas dan sangat memperhatikan kebutuhan masyarakat 
yang datang ke Dinas Pendapatan Daerah Kabupaten Barito Timur.

Secara keseluruhan hasil pene-litian ini mendukung penelitian terda-hulu yang dilakukan oleh Nurhelsa Riana (2013) yang menyatakan bahwa dalam pelaksanaan pelayanan publik memerlukan informasi mengenai wa-ktu kerja para pegawai secara tepat dan terbuka kepada pasien sehingga pasien dapat mengetahui kapan proses pelayanan dilakukan sehinggameng-hemat waktu pasien dalam berobat, perlu adanya tambahan sumber dayamanusia dan peralatan yang memadai untuk membantu pegawai dalam bekerjasecara maksimal.

Hasil penelitian juga sesuai deng-an teori yang dikemukakan oleh Robbins (2013: 121) yang menyatakan bahwa kinerja individu yang optimal dapat dilihat dari kualitas kerja yang baik, kuantitas, ketepatan waktu, efektivitas, kemandirian dan komit-men kerja.

\section{Kendala Yang Dihadapi Dalam Pelayanan Publik Di Dinas Pendapatan Daerah Kabupaten Barito Timur}

Kendala di lapangan saat Pembe-rian pelayanan PBB-P2 dan BPHTB pada Dinas Pendapatan Daerah Kab-upaten Barito Timur dikarenakan berbagai permasalahan yang dihadapi diantaranya adalah :

1) Kinerja Pegawai yang belum optimal

Kendala dalam pelayanan PBB-P2 dan BPHTB pada Dinas Pendapatan Daerah Kabupaten Barito Timur ada-lah Pegawai yang kurang teliti dalam melaksanakan tugas, khususnya dalam menerima dan memeriksa data dan berkas yang diserahkan oleh masya-rakat sebagai pemohon.

Hal ini dapat dilihat pada saat observasi dari banyaknya formulir permohonan yang tidak diisi sesuai dengan ketentuan yang ada sehingga menjadi penghambat atau memper-lambat proses pelayanan PBB-P2 dan BPHTB yang diperlukan oleh masya-rakat.

Perilaku kurang teliti ini, selain ditunjukkan oleh petugas yang meneri-ma formulir permohonan juga ada pa-da petugas perencanaan dan koreksi yang memiliki wewenang dalam mem-berikan disposisi. Hal ini dapat dilihat dari sikap Pegawai yang langsung memberikan tanda tangan tanpa melakukan koreksi terlebih dahulu terhadap berkas permohonan yang masuk hal ini menyebabkan pelayanan PBB-P2 dan BPHTB menjadi terlam-bat dan dan memerlukan waktu tamba-han agar data-data tersebut dapat diperbaiki sebagai mana mestinya sehi-ngga menumpuk diatas meja, dimana hal ini menunjukkan kuantitas kinerja yang masih belum maksimal

Hal ini sama dengan hasil peneli-tian Anitawati (2014) yang menyata-kan bahwa kinerja Pegawai dalam Pelayanan Publik belum maksimal sebagaimana mestinya hal ini terlihat dari hasil kerja pegawai, baik dari segi kemampuan pegawai dalam menye-lesaikan pekerjaan, kualitas pekerjaan yang dihasilkan pegawai, responsibi-litas serta disiplin kerja yang ada diKantor Kecamatan Busang masih banyak kendala yang dihadapi halini disebabkan kurangnya perhatian dari pemerintah kabupaten.

2) Kurangnya Kompetensi Pegawai dan Sosialisasi

Berdasarkan hasil wawancara ke-pada masyarakat yang mendapatkan pelayanan serta diperkuat oleh informan kunci yakni Kepala Dinas Pendapatan Daerah Kabupaten Barito Timur yang menunjukkan bahwa sebagian pegawai ada yang belum memiliki kemampuan untuk mengatasi permasalahan kerja sendiri. Hal ini disebabkan bimbingan teknis/pelatihan belum mereka dapatkan untuk menangani permasalahan terkait masalah tertentu pada pelayanan PBB-P2 dan BPHTB sehingga pelayanan tidak berjalan maksimal.

Hal ini didukung dengan peneliti-an terdahulu yaitu dengan hasil pene-litian Anitawati (2014) yang menya-takan bahwa kinerja Pegawai dalam Pelayanan Publik belum maksimal sebagaimana mestinya hal ini terlihat dari hasil kerja pegawai, baik dari segi kemampuan pegawai dalam menye-lesaikan pekerjaan, kualitas pekerjaan yang dihasilkan pegawai, responsibi-litas serta disiplin kerja yang ada diKantor Kecamatan Busang masih banyak kendala yang dihadapi.

3) Kurangnya Fasilitas Pelayanan

Saat ini Dinas Pendapatan Daerah Kabupaten Barito Timur masih belum memiliki ruang tunggu serta kursi. Hal ini dilihat dari kursi untuk ruang pela-yanan hanya ada 4 
(empat) buah serta meja pelayanan 2 (dua) buah. Karena saat ini bagi masyarakat yang memerlukan pelayanan dari Dinas Penda-patan Daerah Kabupaten Barito Timur menunggu di halaman Kantor dan di ruangan terbuka dan tanpa ada ruangan khusus yang fungsikan seba-gai ruang tunggu. Dari aspek kenya-manan masyarakat sebagai obyek pelayanan hal ini tentu saja masih sangat kurang, karena masyarakat hanya dipersilahkan menunggu di luar ruangan.

Dampak dari tidak adanya ruang tunggu ini adalah tidak jarang masya-rakat yang membutuhkan pelayanan harus rela kepanasan untuk menunggu giliran mendapatkan pelayanan dari Pegawai dan apabila masyarakat tidak sabar maka masyarakat tersebut akan meninggalkan Dinas Pendapatan Daerah Kabupaten Barito Timur dan kembali lagi esok hari.

\section{Solusi Yang Dapat Dilakukan Untuk Mengatasi Kendala Dalam Pelayanan Publik Di Dinas Pendapatan Daerah Kabupaten Barito Timur}

1) Pembinaan Pegawai dan Evaluasi

Masih adanya perilaku Pegawai yang kurang teliti saat menerima dan mengelola data dan berkas dari masya-rakat yang merupakan pemohon me-nyebabkan waktu pelayanan menjadi lebih lambat dan ketidaksesuaian data pada dokumen sehingga menyebabkan proses pelayanan PBB-P2 dan BPHTB menjadi sedikit lambat.

Untuk mengatasi hal tersebut pihak Dinas Pendapatan Daerah Kabupaten Barito Timur akan menga-dakan pembinaan kepada para Pega-wai yang bertugas mengelola data tersebut. Pembinaan Pegawai tersebut ak-an dilakukan melalui evaluasi kinerja yang dilakukan secara berkala mini-mal 1 (satu) bulan sekali. Tujuan dari pembinaan melalui evaluasi kinerja ini adalah untuk mengetahui sejauh mana pelaksanaan tugas yang dilakukan oleh Pegawai dan untuk mengukur sebe-rapa bagus kualitas pelaksanaan tugas Pegawai tersebut. Melalui evaluasi ki-nerja ini apabila diketahui kelemahan-kelemahan dalam pelaksanaan tugas akan dapat segera di perbaiki agar pada bulan berikutnya kesalahan atau kelemahan tersebut tidak terjadi lagi.
Disamping melalui evaluasi kine-rja, pembinaan Pegawai juga akan dilakukan melalui rapat kerja minggu-an yang dilaksanakan setiap akhir pekan atau setiap awal minggu yang ditujukan untuk mengingatkan Pega-wai mengenai aspek-aspek apa saja yang harus diperhatikan dalam melak-sanakan tugas khususnya berkaitan dengan pengelolaan data dan berkas dari pemohon.

2) Bimbingan Teknis dan Sosialisasi

Sebagaimana diketahui, bimbing-an teknis (bimtek) merupakan kegiatan pelatihan dan pengembangan pengeta-huan serta kemampuan yang dapat digunakan untuk memecahkan masalah yang dihadapi oleh setiap pegawai maupun institusi tertentu. Sehingga dengan mengikuti Bimtek PBB-P2 dan BPHTB diharapkan setiap pegawai pada Dinas Pendapatan Daerah, dapat mengambil sebuah manfaat dengan berorientasi pada kinerja dan pelaya-nan terkait PBB-P2 dan BPHTB. Menghadapi kenyataan bahwa semakin tingginya tingkat kompetensi yang dibutuhkan, maka tentunya pelatihan pengembangan SDM ataupun bimtek telah menjadi sebuah kebutuhan untuk individu, instansi, ataupun lembaga pemerintahan.

Masih adanya masyarakat atau pemohon yang menyerahkan formulir dengan data yang belum lengkap, me-nyebabkan waktu pelayanan menjadi lebih lama dan tidak efisien. Hal ini dikarenakan perlu tambahan waktu untuk melengkapi data dan juga melengkapi data tersebut dengan berkas pendukung.

Fenomena ini dapat diatasi deng-an mengadakan sosialisasi kepada masyarakat yang tidak hanya di tingkat Kecamatan akan tetapi juga pada tingkat Desa yakni pentingnya untuk membayar pajak demi kemajuan Kabupaten Barito Timur serta bagai-mana cara atau prosedur pengisian formulir permohonan pelayanan PBB-P2 dan BPHTB, yang mana dalam sosialisasi tersebut hendaknya dijelas-kan kepada masyarakat mengenai tata cara pengisian formulir permohonan pelayanan PBB-P2 dan BPHTB, Misalnya saja penulisan dengan huruf cetak dan pentingnya mengisi seluruh isian pada formulir permohan tersebut.

Melalui sosialisasi ini diharapkan masyarakat akan mengetahui prosedur dan tata 
cara pengisian formulir pem-bayaran $\mathrm{PBB}-\mathrm{P} 2$ dan BPHTB sehing-ga tidak ada lagi formulir pembayaran yang diserahkan dengan data yang belum lengkap, sehingga akan mem-permudah dan mempercepat petugas dalam memproses pelayanan PBB-P2 dan BPHTB sesuai dengan kebutuhan masing-masing masyarakat.

3) Penambahan Fasilitas Ruang Tunggu

Ruang tunggu merupakan elemen penting dalam penyelenggaraan pela-yanan PBB-P2 dan BPHTB pada Dinas Pendapatan Daerah Kabupaten Barito Timur, hal ini dikarenakan ruang tunggu tersebut merupakan fasilitas yang paling sering digunakan oleh masyarakat khususnya yang membutuhkan pelayanan. Untuk mengatasi tidak adanya ruang tunggu di Dinas Pendapatan Daerah Kabupaten Barito Timur, hendaknya pihak Dinas Pendapatan Daerah Kabupaten Barito Timur membangun ruang tunggu demi kenyamanan masyarakat. Hendaknya ruang tunggu tersebut dilengkapi dengan televisi, AC atau kipas angin, dispenser dan beberapa buah bangku atau kursi panjang sebagai tempat istirahat bagi masyara-kat yang sedang menunggu giliran mendapatkan pelayanan dari Pegawai Dinas Pendapatan Daerah Kabupaten Barito Timur sehingga memberikan kenyamanan lebih kepada masyarakat.

Dengan demikian diharapkan ma-syarakat tidak akan merasa bosan selama menunggu giliran mendapat-kan pelayanan PBB-P2 dan BPHTB dari Dinas Pendapatan Daerah Kabupaten Barito Timur.

Penelitian ini sama dengan hasil penelitian Nurhelda Riana (2013) berjudul Analisis Kinerja Pegawai Dalam Pelaksanaan Pelayanan Publik di Puskesmas Maridan Kecamatan Sepaku Kabupaten Penajam Paser Utara yang diperoleh bahwa kinerja pegawai dalam pelaksanaan pelayanan publik di Puskesmas Maridan Kecamatan Sepaku Kabupaten Penajam Paser Utara belum berjalan secara maksimal hal ini karena masih kurangnya sum-ber daya manusia dibutuhkan, peralatan yang mendukung dalam pelaksana-an pelayanan masih kurang, kedisiplinan dan tanggungjawab pegawai dalam bekerja masih belum maksimal.

\section{KESIMPULAN}

1) Kinerja pegawai Dinas Pendapa-tan Daerah Kabupaten Barito Timur dilihat dari indikator kinerja seperti kualitas, Efektivitas dan komitmen kerja sudah baik akan tetapi kuantitas kerja, ketepatan waktu pelaksanaan tu-gas, kemandirian dalam mengha-dapi masalah pekerjaan pada pelayanan PBB-P2 dan BPHTB masih belum terlaksana secara optimal.

2) Kendala Yang Dihadapi Dalam Pelayanan Publik Di Dinas Pen-dapatan Daerah Kabupaten Barito Timur, yaitu : a) Kinerja Pegawai yang belum optimal, b) Kurangnya Kompetensi Pegawai dan Sosialisasi,dan c) Kurangnya Fasilitas Ruang Tunggu.

3) Solusi Yang Dapat Dilakukan Untuk Mengatasi Kendala Dalam Pelayanan Publik Di Dinas Pen-dapatan Daerah Kabupaten Barito Timur, yaitu : a) Pembinaan Pega-wai dan Evaluasi b) Bimbingan Teknis (Bimtek) dan Sosialisasi, dan c) Penambahan Fasilitas ruang tunggu.

Sehubungan dengan itu diharapkan pihak Dinas Pendapatan Daerah Kabupaten Barito Timur perlu memberikan pembinaan kepada Pegawai serta diadakannya Evaluasi. Dinas Pendapatan Daerah Kabupaten Barito Timur perlu Bimbingan Teknis terkait Pelayanan PBBP2 dan BPHTB kepada Pegawainya dan Sosialisasi di tingkat Kelurahan/Desa. Pihak Dinas Pendapatan Daerah Kabupaten Barito Timur perlu peningkatan fasilitas sarana dan prasarana pelayanan.

\section{REFERENSI}

Abdulah. 2014. Evaluasi Kinerja, Jakarta : Bumi Aksara.

Dharma, Agus 2014. Manajemen Kinerja.Yogyakarta : Pustaka Pelajar

Mangkunegara, Anwar Prabu, 2010. Manajemen Sumber Daya

Manusia Perusahaan. Bandung : PT. Rosdakarya. 
Moenir, AS. 2011. Manajemen Pelayanan Umum di Indonesia, Cetakan III, Jakarta: Bina Aksara.

Rahayu, Iswiyati. 2011. Manajemen Pelayanan Publik, Sekolah Tinggi Ilmu Administrasi (STIA) Bina Banua Banjarmasin
Robbin,Stephen P. 2013. Teori Perilaku Organisasi, Jakarta : Erlangga

Soetopo, 2014, Manajemen Pelayanan Publik, Jakarta: Rineka Cipta.

Wibowo, 2010. Manajemen Kinerja. Jakarta : Rajawali Pers. 